International Journal of Economics, Business and Management Research

Vol. 6, No.01; 2022

ISSN: $2456-7760$

\title{
The Role of Neutral Information and Accounting Information of Women Investors in Investing in the Sharia Capital Market
}

\author{
Maliah $^{1}$, Maya Panorama ${ }^{2}$ \\ ${ }^{1}$ Universitas PGRI Palembang \\ ${ }^{2}$ Universitas Islam Negeri Raden Fatah Palembang \\ doi: 10.51505/IJEBMR.2022.6103 \\ URL: http://dx.doi.org/10.51505/IJEBMR.2022.6103
}

\begin{abstract}
Investment is the ability of investors to postpone part of their income today to consume in the future, the expectation is that future consumption in real terms will be greater than today's consumption. The type of this research is quantitative research with total sample of 150 respondents and using multiple linear regression tests. The object of this research is female investors in the Islamic capital market at Palembang city. The results showed that neutral information has no effect to investment because respondents use feelings more than information and analysis about stocks. Accounting information has effect because respondents can read and analyze the financial statements and investors take into account the estimated future profits of the company which is an economic variable to maximize wealth.
\end{abstract}

Keywords: Neutral Information, Accounting Information, Female investors, Investment

\section{Introduction}

One of the efforts made by Indonesia to improve the quality of its economy is to grow the investment sector by using capital market instruments. For this reason, the capital market sector is one sector that is highly considered in Indonesia. In addition, the capital market is also an important instrument in today's world economy, considering that the capital market, like banking, is a medium that can become a bridge for those who have excess and need capital. In it are connected so many economic actors without national borders. (Yusuf et al., 2021)

Investment is the ability of investors to postpone part of their income today to consume in the future, the expectation is that future consumption in real terms will be greater than today's consumption. It is implicit that investment is a productive activity by carrying out activities in the real sector and/or financial sector by expecting a return or compensation for the risks of such productive efforts. Investments can be made in the form of financial products such as deposits, stocks, and bonds, while investments in non-financial products are property, gold, and setting up their own business. Each form of investment has different risks and returns, this is what an investor needs to understand. (Ngkat et al., 2015)

Investing needs to be done by everyone because it can increase the value of current assets or wealth or as part of financial planning for the future, such as preparing a pension fund, preparing a child's education fund, and so on. In this way, future needs can be met. (Kawitan et al., 2015) Investment now becomes a trend in the modern age that is needed by everyone. The investment itself can be interpreted as an effort that we are doing now to get results in the future. The capital market sector is currently one of the most popular places to invest because of the convenience it 


\section{International Journal of Economics, Business and Management Research}

Vol. 6, No.01; 2022

ISSN: $2456-7760$

offers. There are almost countless amounts of daily fund turnover in the capital market. The capital market itself actually aims to support the implementation of national development in equity, growth, and stability of the national economy for the welfare of the community. (Lemiyana, 2019)

With the increasing development of investment, financial behavior plays a very important role in making a person's decision to invest. Financial decision-making for investment activities will be greatly influenced by the information obtained and the knowledge of investors about investment. Usually, an investor will do research before deciding to invest, such as by studying the company's financial statements, company performance, track record or portfolio, economic conditions, risks, reviews of finances and economic conditions published in the media, and others. with the aim that the investments made can provide additional wealth (Mahastanti, 2011) Investment based on the Islamic concept is actually no different from the conventional concept philosophically. Investment (conventional) is the purchase of securities and immovable goods or saving funds as capital to a company so that the funds provide sustainable profits and the results become the property of investors. While the concept of investment according to Islam (sharia) is an investment entity that is based on sharia principles, halal investment and avoids the practices of usury, gharar and maysir. (Peristiwo, 2016)

One of the attitudes that market players have in the capital market sector is the intention to invest. Intention to invest is a cognitive process to estimate risk and return. This form of attitude is supported by three factors, namely: first, determination: strong motivation, intention, and purpose. Second, self-discipline: knowing what and when to do something. Third, fighting: hard work, smart work, and time management. The process of intention to invest requires high capabilities for market participants related to individual abilities in cognitive, affective, and emotional aspects such as processing of financial and non-financial information, application of investment knowledge from fundamental and technical aspects, changes in investment preferences, perceptions of risk and return, and learning the investment process. (Septyanto, 2013)

In Indonesia, the development of the Islamic capital market has occurred since 1997, which began with the birth of sharia mutual funds initiated by mutual funds. The basic principles of the Islamic capital market are certainly different from conventional ones. A number of sharia instruments in the capital market have been allowed to the public, such as sharia shares, sharia bonds (Sukuk), and sharia mutual funds. (Nurul Huda, 2008)

The Islamic capital market is a capital market that is run with the concept of sharia, where every securities trade complies with the provisions of transactions in accordance with sharia provisions. The Islamic capital market does not only exist and develop in Indonesia but also in other countries, such as Malaysia. The first institution that paid attention to operating its portfolio with Islamic portfolio management in the Islamic market was the Amanah Income fund which was founded in June 1986 by members of The North American Islamic Trust based in Indiana, United States of America. 


\section{International Journal of Economics, Business and Management Research}

Vol. 6, No.01;2022

ISSN: $2456-7760$

\section{Graph 1. \\ Investor Growth by Gender}

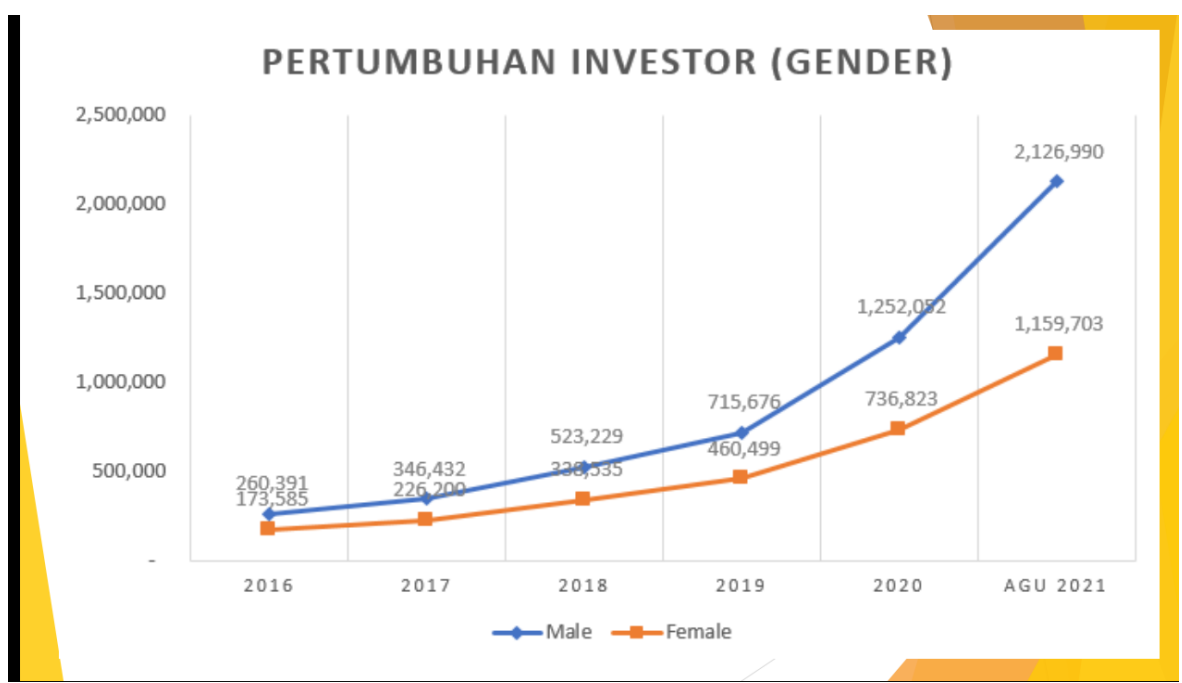

Source: Indonesia Stock Exchange, 2021

The capital market is no longer synonymous with the activities of men. Now women are even more active in investing in the capital market. This condition is reflected in data on the growth in the number of domestic capital market investors reported by the Indonesian Central Securities Depository (KSEI) as of April 2018. Based on Graph 1, the number of investors in the Indonesian capital market by gender in 2021 has increased every year. In August 2021 the percentage of female investors was only $35 \%$ growth, the biggest challenge for women to invest is lack of confidence. In fact, household finance managers are women. Women should start investing early, even before starting a family. Women must dare to get out of their comfort zone by exchanging the current consumptive culture, with investment as a new lifestyle The capital market is no longer synonymous with the activities of men. Now women are even more active in investing in the capital market. This condition is reflected in data on the growth in the number of domestic capital market investors reported by the Indonesian Central Securities Depository (KSEI) as of April 2018. Based on Graph 1, the number of investors in the Indonesian capital market by gender in 2021 has increased every year. In August 2021 the percentage of female investors was only $35 \%$ growth, the biggest challenge for women to invest is lack of confidence. In fact, household finance managers are women. Women should start investing early, even before starting a family. Women must dare to get out of their comfort zone by exchanging the current consumptive culture with investment as a new lifestyle. The capital market is no longer synonymous with the activities of men. Now women are even more active in investing in the capital market. This condition is reflected in data on the growth in the number of domestic capital market investors reported by the Indonesian Central Securities Depository (KSEI) as of April 2018. Based on Graph 1, the number of investors in the Indonesian capital market by gender in 2021 has increased every year. In August 2021 the percentage of female investors was only $35 \%$ growth, the biggest challenge for women to invest is lack of confidence. In fact, household finance managers are women. Women should start investing early, even before 


\section{International Journal of Economics, Business and Management Research}

Vol. 6, No.01; 2022

ISSN: $2456-7760$

starting a family. Women must dare to get out of their comfort zone by exchanging the current consumptive culture, with investment as a new lifestyle

Investors in the world of capital markets have preferences (trends) and characters that are different from one another, and because of these differences, an investment manager is required to understand and analyze the typical and behavior of investors in investing activities. With this basic understanding, an investment manager is expected to be able to select and select the right, appropriate and optimal type of securities or portfolio for each investor as a whole. (Nurul Huda, 2008) In general, female investors rely more on themselves when making investment decisions than looking for other sources of information. Women are usually more careful in managing their finances, therefore by investing, they will be more able to manage their future and that of their family. (Lemiyana, 2019)

Neutral Information factors can influence someone to invest where investors will get information from outside showing a picture so that the information obtained is not biased, this information includes reviews and information from the media about finance and economic conditions related to investment activities which includes information about news or reviews in the financial media which usually discusses the current state or condition with the development of existing investments as well as other matters related to investment and finance, news or reviews in the general media, changes in stock prices, reviews from financial analysts published on media, and economic indicators (inflation, interest rates, etc.).(Nagy Robert A., 1994)

Most investors in their investment decisions only see and consider Accounting Information factors so that their investment goals are achieved, but other factors are not given much attention. These factors are commonly referred to as traditional analytical tools and investors usually feel that it is enough to see these two factors to determine investment decisions, besides that many investors do not know that there are other factors that can be taken into consideration before investing. Information about financial statements is easy to obtain and use as an assessment of the company's condition and profitability so that it is still an object of evaluation in making investment decisions. According to (Mahastanti, 2011) Information about financial statements is easily obtained by investors and is used as a reference for evaluating the company's financial condition and company profitability so that it is used as an object of investor evaluation in making investment decisions.

Research conducted by (Al-tamimi, 2014) against investors in Dubai (UAE) stated that the factors that are most considered by investors are the income generated by the company, the ability of past company shares where these factors are included in the category of Neutral information and Accounting Information. Investors consider more economic factors that can increase investor wealth, while investors also do not consider religious factors in investing. According to (Lotto, 2020) that the accounting information variable is not related to a person's decision to invest. This study aims to determine the role of Neutral Information and accounting information for female investors to invest in the Islamic capital market.

\section{Literature Review}

Heuristic Theory

Heuristic is a rule of thumb for someone in making decisions because of uncertain (complicated) situations, circumstances, or environmental impacts. Heuristics are decision making based on 


\section{International Journal of Economics, Business and Management Research}

Vol. 6, No.01; 2022

ISSN: $2456-7760$

available information. Kahneman dan Tversky (1979) see that when making decisions, investors are irrational (Daniel Kanheman, 1979)

\section{Economic Factors}

Economic factors are considerations by investors before deciding to invest. Factors related to the decision include the tendency for investors to consider various information that is closely related to financial statements and other factors. Economic factors consist of neutral information, accounting information and classic. (Kusumawati, 2013) In this study using factors neutral Information, accounting information.

\section{Investment}

Investment comes from Latin, namely investire (to use), while in English it is called investment. According to Fitzgerald in (Manan, 2009) interpreting investment is an activity related to the withdrawal of resources (funds) that are used to procure capital goods at the present time, and with capital goods a stream of new products will be generated in the future

According to (Bodie, Kane, 2004) an investment is the current commitment of money or other resources in the expectation of reaping future benefit. For example, an individual might purchase share on stock anticipating that the future proceeds from the share will justify both the time that her money is tied up as well as the risk of the investment. According to (Robbins, 2006) the dimensions of investment are as follows: Investment Benefits, Investment Capital, Motivation, Return and Education.

\section{Neutral Information}

Neutral Information includes economic indicators, stock price movements, information obtained on the internet, and government statements that will influence investor decisions. (Babikir, 2017) Neutral Information states that neutral information provides a lot of different information, so investors also need to see how the feedback is between the fundamentals of a stock, external risks and also the value of the stock. This variable has a correlation between financial theory and empirical evidence so that it can be used as a reference for investors to decide to invest in stocks. (Akbar et al., 2016) Information indicators are news/reviews in the media, the economy, changes in stock prices, economic indicators and financial analysis. (Nagy Robert A., 1994)

\section{Accounting Information}

Accounting information is a collection of information related to the financial statements of a company. This report consists of how to report the track record of a company, information on the overall financial statements of the company, reports on the progress of company acquisitions, reports on the progress of company profits/profits, and reports on company share prices. (Kusumawati, 2013) Indicators of accounting information are data on reports and prospectus, valuation of shares by calculating NPV, IRR, etc., expected company income or profit, history of company establishment, and current stock market capability Indicators of accounting information are data on reports and prospectus, valuation of shares by calculating NPV, IRR, etc., expected company income or profit, history of company establishment, and current stock market capabilities. (Nagy Robert A., 1994) 


\section{Framework of Thinking}

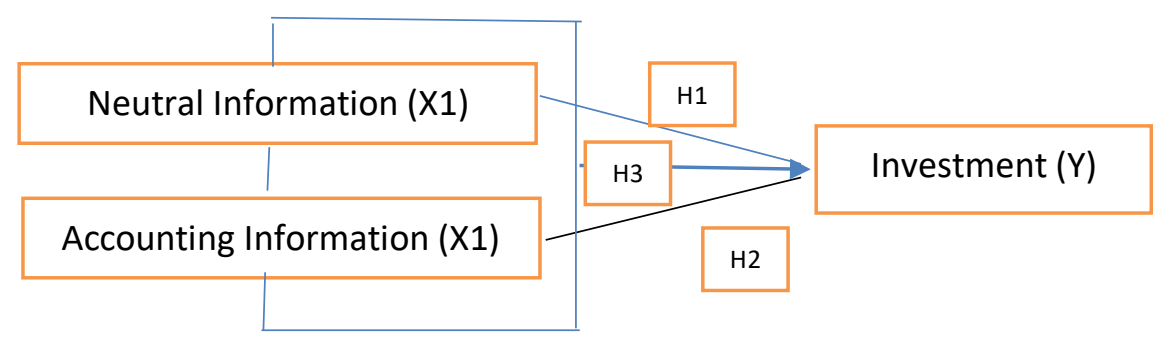

Figure 1. Conceptual Framework

\section{Hypothesis}

The hypotheses in this study are as follows:

H1: Neutral Information has an effect on female investors investing in the Islamic capital market

$\mathrm{H} 2$ : Accounting information has an effect on female investors investing in the Islamic capital market

H3: Neutral Information and Accounting information for female investors investing in the capital market

\section{Research Methodology}

In this study, the primary data source in the form of words was obtained from interviews with predetermined informants covering various matters relating to women investors in the Islamic capital market in the city of Palembang.

This study uses a non-probability sampling technique. In this technique the sample selection does not use a random process; population members are selected on the basis of certain considerations. Furthermore, a sampling technique is used based on Judgmental Sampling or certain considerations, where only female investors invest in the Palembang City Sharia Capital Market. Samples were obtained as many as 150 female investors.

In collecting data, this research used a survey method, where respondents answered a list of questions (questionnaires) that had been prepared. The list of questions (questionnaires) was filled out by the respondents and returned to the researcher. The respondents are female investors in the Islamic Capital Market in Palembang City. The Likert scale is based on the consideration that this research is used to measure the attitudes, opinions and perceptions of respondents about social phenomena around them. (Sugiyono, 2009)

Data processing is done by testing the validity, reliability of classical assumptions and multiple regression with hypothesis testing. The multiple equation model is as follows:

$$
\mathrm{Y}=\mathrm{a}+\mathrm{b} 1 \mathrm{X} 1+\mathrm{b} 2 \mathrm{X} 2+\mathrm{e}
$$


Vol. 6, No.01; 2022

ISSN: $2456-7760$

Where:

Y: investment

A: constant

b1: coefficient of X1

b2: coefficient of X2

$\mathrm{X} 1$ : Neutral Information

$\mathrm{X} 2$ : Accounting information

e: error

\section{Result}

This study collects data using various techniques, including interview, observation, documentation studies, and questionnaires. Description of the characteristics of research respondents as follows

The distribution of respondents by age can be described as in Table 2:

Table 1. Distribution of Respondents by Age

\begin{tabular}{|l|l|l|l|}
\hline No & Ages & Amount people & Percentage $(\boldsymbol{\%})$ \\
\hline 1. & $<20$ years & 52 & 34.67 \\
\hline 2. & $21-30$ year & 40 & 26.67 \\
\hline 3. & $31-45$ year & 34 & 22.26 \\
\hline 4. & $>$ 45 years & 24 & 16 \\
\hline Total & $\mathbf{1 5 0}$ & $\mathbf{1 0 0}$ \\
\hline
\end{tabular}

Source: primary data processed, 2021

Based on Table 2 above, it can be seen that the majority of respondents are in the age range under 20 years as many as $34.67 \%$ or 52 people and $21-30$ years, respectively, as many as $26.67 \%$ or 40 people. For the age range of 31 - 45 years as many as $22.66 \%$ or 34 people and over 45 years or as many as $16 \%$ or 24 people.

The distribution of respondents according to their education level is depicted in Table 2:

Table 2. Distribution of Respondents by Education Level

\begin{tabular}{|c|c|c|c|}
\hline No & Level of education & Amount people & Percentage $(\%)$ \\
\hline 1. & Primary & - & - \\
\hline 2. & Secondary & - & - \\
\hline 3. & High & 78 & 52 \\
\hline 4. & Degree & 72 & 48 \\
\hline 5. & Others & - & - \\
\hline \multicolumn{2}{|c|}{ Total } & 150 & 100 \\
\hline
\end{tabular}

Source: primary data processed, 2021 


\section{International Journal of Economics, Business and Management Research}

Vol. 6, No.01; 2022

ISSN: $2456-7760$

Table 2. shows that most respondents (52\%) or 78 respondents have a high school education level, then $48 \%$ percent or 72 respondents have a bachelor's level of education.

The distribution of respondents by type of work is described in Table 3

Table 3. Distribution of Respondents by Type of Work

\begin{tabular}{|l|l|l|l|}
\hline No & Type of Work & Amount people & Percentage (\%) \\
\hline 1. & Student and College & 54 & 36 \\
\hline 2. & Private employees & 63 & 42 \\
\hline 3. & Civil servant & 4 & 2.7 \\
\hline 4. & entrepreneur & 29 & 19.3 \\
\hline \multicolumn{2}{|l|}{ Total } & $\mathbf{1 5 0}$ & $\mathbf{1 0 0}$ \\
\hline
\end{tabular}

Source: primary data processed, 2021

Table 3 shows that most of the respondents 63 respondents or $42 \%$ of respondents are private employees, $36 \%$ or 54 respondents are students, entrepreneurs' respondents are 29 people or $19.3 \%$ and civil servants are 4 respondents or $2.7 \%$.

The distribution of respondents by income level is described in Table 4

Table 4. Distribution of Respondents by Income Level

\begin{tabular}{|l|l|l|l|}
\hline No & Income Level & Amount people & Percentage (\%) \\
\hline 1. & $<\operatorname{Rp~1.000.000~}$ & 46 & 30.67 \\
\hline 2. & Rp 1.000.000 s/d Rp 3.000.000 & 24 & 16 \\
\hline 3. & Rp 3.000.000 s/d Rp 5.000.000 & 35 & 23.33 \\
\hline 4 & Rp 5.000.000 s/d Rp 7.000.000 & 26 & 17.33 \\
\hline 5 & Rp 7.000.000 s/d Rp 8.000.000 & 11 & 7.33 \\
\hline 6 & $>\operatorname{Rp~} 8.000 .000$ & 8 & 5.34 \\
\hline \multicolumn{2}{|l|}{ Total } & $\mathbf{1 5 0}$ & $\mathbf{1 0 0}$ \\
\hline
\end{tabular}

Source: primary data processed, 2021

Table 4 shows that most of the respondents or as many as 46 respondents or 30.67 percent have income $<$ Rp. $1,000,000.00$, the number of respondents is 35 people or $23.33 \%$ of respondents have income of Rp.3,000,000 to Rp.5,000,000, 26 respondents or 17.33 percent of respondents have an income level of Rp. 5,000,000 - Rp. 7,000,000. for income levels <Rp. 1,000,000 as many as 46 respondents or $30.67 \%$. while the income level is Rp. 7,000,000 to Rp. 8,000,000 as many as 11 respondents or $5.34 \%$. while those who have an income level of more than Rp. $8,000,000$ as many as 8 respondents or by $5.34 \%$.

The distribution of respondents according to marital status is described in Table 5 
Table 5. Distribution of Respondents by Marital Status

\begin{tabular}{|l|l|l|l|}
\hline No & Marital Status & Amount people & Percentage (\%) \\
\hline 1. & Marry & 64 & 42.67 \\
\hline 2. & Not Married yet & 86 & 57.33 \\
\hline \multicolumn{2}{|l|}{ Total } & $\mathbf{1 5 0}$ & $\mathbf{1 0 0}$ \\
\hline
\end{tabular}

Source: primary data processed, 2021

Table 5 shows that most of the respondents as many as 86 respondents or 57.33 percent are unmarried and those who are married are 64 respondents or 42.67 percent.

The distribution of respondents according to their length of time as investors is depicted in Table 6

Table 6. Distribution of Respondents based on length of time being an investor

\begin{tabular}{|l|l|l|l|}
\hline No & Length of time & Amount people & Percentage (\%) \\
\hline 1. & $<1$ year & 27 & 18 \\
\hline 2. & $1-3$ years & 68 & 45.33 \\
\hline 3. & $>$ 3 years & 55 & 36.67 \\
\hline Total & $\mathbf{1 5 0}$ & $\mathbf{1 0 0}$ \\
\hline
\end{tabular}

Source: primary data processed, 2021

Table 6 shows that most of the respondents or 45.53 percent or 68 respondents have been customers/investors for 1-3 years, for $>3$ years as many as 36.67 percent or 55 respondents. The remaining 18 percent or 27 respondents have become investors.

The results of the analysis of the validity of each variable to 150 respondents in the study consisting of: Neutral information (X1), Accounting Information (X2) and Investment (Y) showed significant for all tested variables, where all Pearson correlation values ( $\mathrm{r}$ count) generated is greater than 0.30 so that the resulting data can be analyzed further.

The reliability test of a data is seen from the Cronbach's Alpha coefficient. The results of the analysis of the reliability of each variable in the study consisting of: Neutral information (X1), Accounting Information (X2) and Investment (Y) showed significant for all variables tested, where all Cronbach's Alpha values> 0.60

The results of the normal probability plot curve show that the points on the Graph 2, coincide and follow the diagonal line, so it can be concluded that the regression model is normally distributed. 
Vol. 6, No.01; 2022

ISSN: 2456-7760

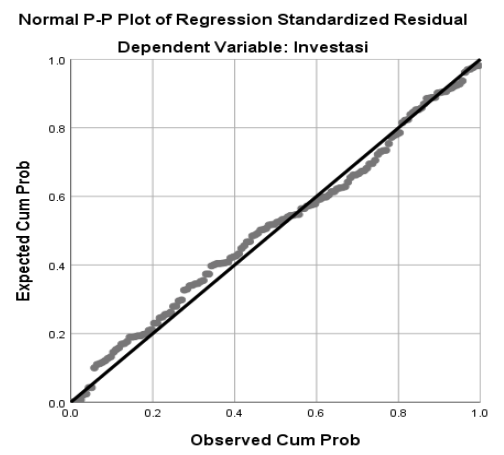

Graph 2 P-P Plot Normality Test

Source: primary data processed, 2021

The results of the Heteroscedasticity test in Figure 3 show that there is no clear pattern and the points are spread above and below the number 0 on the $\mathrm{Y}$ axis, so there is no heteroscedasticity. It means that the model is good.

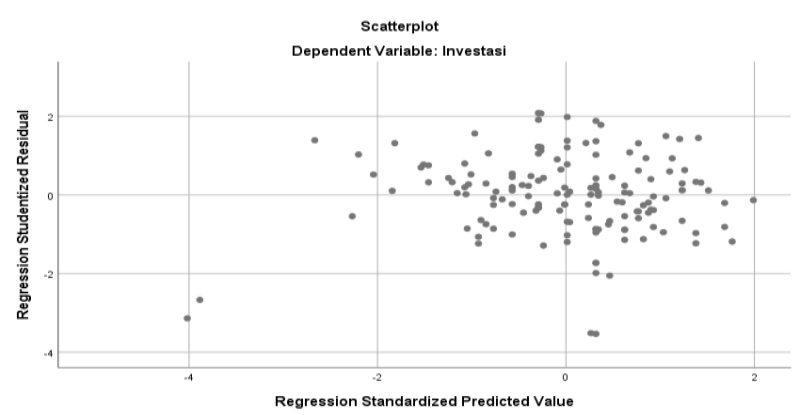

Figure 3. Heteroscedasticity test

Source: primary data processed, 2021

It is known in Table 7, that each VIF value is $1.553<10$ and the tolerance value is $>0.10$, so it can be concluded that there is no multicollinearity in the regression model.

Table 7. Multicollinearity Test

\begin{tabular}{|c|c|c|c|}
\hline \multicolumn{2}{|c|}{ Model } & \multicolumn{2}{|c|}{$\begin{array}{l}\text { Collinearity } \\
\text { Statistics }\end{array}$} \\
\hline 1 & (Constant) & & \\
\hline & $\begin{array}{l}\text { Neutral } \\
\text { information }\end{array}$ & .644 & 1.553 \\
\hline & $\begin{array}{l}\text { Accounting } \\
\text { information }\end{array}$ & .644 & 1.553 \\
\hline
\end{tabular}

Source: primary data processed, 2021 
Vol. 6, No.01; 2022

ISSN: $2456-7760$

Correlation explains the relationship between the independent variables Neutral Information and Accounting Information arranged in the regression equation model on the Investment variable. While the coefficient of determination explains how much of the contribution given by the independent variable to the investment variable, the following is presented in Table 8.

Table 8. Results of Correlation Analysis and Coefficient of Determination

\section{Model Summary}

\begin{tabular}{ll|l|l|l|l} 
Model & R & R Square & $\begin{array}{l}\text { Adjusted } \\
\text { Square }\end{array}$ & R & $\begin{array}{l}\text { Std. Error of } \\
\text { the Estimate }\end{array}$ \\
\hline 1 & $.314^{\mathrm{a}}$ & .099 & .086 & 11.68277 \\
\hline
\end{tabular}

a. Predictors: (Constant), Accounting information, Neutral information

b. Dependent Variable: Investment

Source: primary data processed, 2021

Based on Table 8, the adjusted R Square value of 0.086 means that only $08.6 \%$ of investment can be explained by the Neutral Information and Accounting Information variables, while most of the other $91.4 \%$ investments can be explained by other variables. The small adjusted $\mathrm{R}$ square value is due to other factors that influence the investment variable. Because in practice other factors such as company reputation, stock prices also affect investment. The results of the Neutral Information and Accounting Information variables which are not significant also affect the smaller adjusted $\mathrm{R}$ value.

The Simultaneous test was carried out to test the effect of the independent variables together on the dependent variable Y. In the joint hypothesis test, the F test was used. The Simultaneous test results are presented in Table 9 below:

Table 9. F Test

\begin{tabular}{|c|c|c|c|c|c|c|}
\hline \multicolumn{7}{|c|}{ Anova } \\
\hline Model & & $\begin{array}{l}\text { Sum } \\
\text { Squares }\end{array}$ & Df & Mean Square & $\mathrm{F}$ & Sig. \\
\hline \multirow[t]{3}{*}{$\overline{1}$} & Regression & 2193.482 & 2 & 1096.741 & 8.035 & $.000^{\mathrm{b}}$ \\
\hline & Residual & 20063.591 & 147 & 136.487 & & \\
\hline & Total & 22257.073 & 149 & & & \\
\hline
\end{tabular}

a. Dependent Variable: Investment

b. Predictors: (Constant), Accounting information, Neutral Information

Source: primary data processed, 2021

Table 9 explains the feasibility of the regression model to determine the effect of the independent variables $\mathrm{X} 1$, and $\mathrm{X} 2$ on the $\mathrm{Y}$ variable and to test whether the linear model is correct or not, the calculated $\mathrm{F}$ in the Anova Table needs to be compared with the F table.

a) $\mathrm{F}$ table depends on the probability and the degree of freedom (df). Degree of freedom (df) to determine $\mathrm{F}$ There are two tables, namely df the numerator (N1) and df the denominator (N2). 


\section{International Journal of Economics, Business and Management Research}

Vol. 6, No.01; 2022

ISSN: 2456-7760

Where dfN1=Number of Variables- 1 , so we get $\mathrm{dfN} 1=3-1=2$, while df $\mathrm{N} 2=$ number of sample data-Number of variables. So, we get $\mathrm{dfN} 2=150-3=147$. Thus, if we use $=5 \%$, we get $\mathrm{F}$ Table $(\mathrm{N} 1, \mathrm{~N} 2)=\mathrm{F}(2,123)=3.06$

b). Based on the F test, it is obtained that the calculated F value is $8035>\mathrm{F}$ Table 3.06, and the sig value $(\mathrm{P}$ value $)=0.000<0.05$, this shows that Neutral Information and Accounting Information have a positive and significant effect on investment.

The following Table 10, inform the result of regression coefficients used as the basis for the partial test.

Table 10. T Test

\begin{tabular}{|c|c|c|c|c|c|c|}
\hline \multirow[t]{2}{*}{ Model } & & \multicolumn{2}{|c|}{$\begin{array}{l}\text { Unstandardized } \\
\text { Coefficients }\end{array}$} & \multirow{2}{*}{$\begin{array}{l}\text { Standardized } \\
\text { Coefficients } \\
\text { Beta }\end{array}$} & \multirow[t]{2}{*}{$\mathrm{t}$} & \multirow[t]{2}{*}{ Sig. } \\
\hline & & $\mathrm{B}$ & Std. Error & & & \\
\hline \multirow{3}{*}{1} & (Constant) & 52.462 & 7.094 & & 7.395 & .000 \\
\hline & Neutral information & -.102 & .321 & -.031 & -.317 & .752 \\
\hline & $\begin{array}{l}\text { Accounting } \\
\text { information }\end{array}$ & 1.170 & .345 & .331 & 3.396 & .001 \\
\hline
\end{tabular}

Source: primary data processed, 2021

a. $\mathrm{T}$ table depends on the probability and the degree of freedom (df). Where the number of $\mathrm{df}=$ $\mathrm{N}-\mathrm{K}$. So, we get $\mathrm{df}=150-3=147$. Thus, if we use $=5 \%$, we get $\mathrm{t}$ table $(\alpha, \mathrm{df})=\mathrm{t}(0.05,147)=$ 1.65529 .

b. The value of the Neutral Information coefficient is -1.02 with a negative value. This means that for every 1 time increase in Neutral Information, the investment will decrease by 1.02 assuming the other variables are constant. Based on the first hypothesis in this study the Neutral Information variable, the t-count value -1.02 is smaller than the t-table 1.655 and a significance value of 0.752 is obtained which is greater than the 0.05 significance level $(0.752$ $>0.05$ ). Therefore, the hypothesis is rejected so that it can be concluded that Neutral Information has no effect on investment

c. The Accounting Information coefficient value is 1.170 with a positive value. This means that for every 1 time increase in Accounting Information, the investment will increase by 1,170 assuming the other variables are constant. The Accounting Information variable has a t-count value of 3.396 which is greater than the t-table of 1.681 and a significance value of 0.001 is obtained which is smaller than a significance level of $0.05(0.001<0.05)$. Therefore, it can be concluded that the hypothesis is accepted, meaning that Accounting Information has an effect on investment.

\section{Discussion}

The Role of Neutral Information for Female Investors in Investing in the Islamic Capital Market

The findings in this study indicate that the neutral information variable of female investors has no effect on investment in the Islamic capital market. This shows that outside information such 


\section{International Journal of Economics, Business and Management Research}

Vol. 6, No.01;2022

ISSN: $2456-7760$

as reviews in the financial media, the general state of the economy is not important as an investment consideration for female investors in the Islamic capital market in the city of Palembang. Reviews that are usually carried out by experts in the analysis are not taken into consideration.

Based on the education level of the respondents, it is dominated by female respondents with a bachelor's and high school education level, which is a fairly high level of education. At this level of education, it can be classified as $>25$ years old, i.e., investors already have better knowledge and thinking, where to analyze and make decisions as investors and choose the better invest for them. The level of education will affect a person's investment decisions, with a high level of education that does not make investors confident in determining which factors are more important. Investors who graduate from undergraduate studies still consider all factors related to their investment activities.

According to (Sjahrir, 1995) investor's decision tend to base on rumors, issues, speculative, and mass behavior, impulsivity, loss-control, and impatience so that investors' behavior is more influenced by following their hearts so that investment decisions experience a high risk. This is because the perception of the object being interpreted is misinterpreted. Female investors use feelings more than information and analysis about stocks.

Research conducted by (Khairani \& Putri, 2009) that women have emotional warmth, care and sensitivity than men. As for the emotional level, women are more emotional so that the level of emotional maturity is low compared to men who are more rational and use logic so that the level of emotional maturity is higher. The results of this study are not in line with the research (Mahastanti, 2011) that the Neutral Information factor is a factor that investors consider in making investments.

\section{The Role of Accounting Information for Female Investors in Investing in the Islamic Capital Market}

The findings in this study indicate that the accounting information variable of female investors has an effect on investment in the Islamic capital market. This shows that female investors in investing are very concerned about the company's financial statements, including data on reports and prospectus, valuation of shares by calculating NPV, IRR, etc., expected company income or profit, history of company establishment, and stock exchange capabilities. at the moment.

According to Robert, (Nagy Robert A., 1994) that Accounting information are several factors that can influence someone to invest. Investors are now different in investing, now investors take into account the estimated future profits of the company which is an economic variable to maximize wealth. Women have a higher prudence character than men in investment decisions. This can be supported by classifying expressive characteristics. Other research mentioned that (Setiawati Devi, 2009) Women are not very independent, very emotional, very illogical, difficult to make decisions, not very confident, and desperately need a sense of security.

This research is inversely proportional to the results of the study (Septyanto, 2013) that accounting information has no effect on investment because information signals in financial 


\section{International Journal of Economics, Business and Management Research}

Vol. 6, No.01; 2022

ISSN: $2456-7760$

statements are not able to make investors to make changes to previously held beliefs whether they have good news or bad news signals.

\section{Conclusion}

Based on the results of the research analysis, conclusions can be drawn

1. Neutral Information of Female Investors has no effect on investment in the Islamic Capital Market

2. Accounting information for female investors affects investment in the Islamic capital market

\section{Acknowledgment}

Agus Tri Basuki, Nano Prawoto. (2016). Analisis Regresi Dalam Penelitian Ekonomi Dan Bisnis. Rajagrafindo Persada.

Akbar, M., Salman, A., Mughal, K. S., Mehmood, F., Makarevic, N., \& Campus, I. (2016). Factors Affecting the Individual Decision Making: a Case Study of Islamabad Stock Exchange. European Journal of Economic Studies, 15, 242-258. https://doi.org/10.13187/es.2016.15.242

Al-tamimi, H. A. H. (2014). Factors Influencing Individual Investor Behaviour : An Empirical study of the UAE Financial Markets, The Business Review, Cambridge, Vol. 5, No . 2, 225-232, The Business Review, 5(2), 225-232.

Arikunto, S. (2002). Prosedur Penelitian Suatu Pendekatan Praktek (Cet.XII). PT. Rineka Cipta.

Babikir, M. O. E. (2017). Factors Affecting Stock Prices in Saudi Stock Market From the. International Journal of Business and Management Review, 5(8), 30-42.

Bodie, Kane, M. (2004). Essentials of Investment. McGraw Hill.

Daniel Kanheman, A. T. (1979). Prospect Theory: An Analysis of Decision under Risk. Econometrica, 47(No.2 Mar), 263-291.

Hartono. (2014). SPSS 16.0: Analisis Data Statistika dan Penelitian. Pustaka Pelajar.

Kawitan, J., Memarista, G., Ekonomi, F., Petra, U. K., \& Siwalankerto, J. (2015). Faktor-faktor yang Mempengaruhi Investasi di Reksadana. 3(2), 49-54.

Khairani, R., \& Putri, D. E. (2009). Perbedaan Kematangan Emosi Pada Pria Dan Wanita Yang. Proceeding PESAT (Psikologi, Ekonomi, Sastra, Arsitektur, \& Sipil), 3, 20-21.

Kusumawati, M. (2013). Faktor Demografi, Economic Factors Dan Behavioral Motivation Dalam Pertimbangan Keputusan Investasi Di Surabaya. Jurnal Finesta, 1((2)), 30-35.

Lemiyana. (2019). Gaya Hidup Investor Perempuan Modern di Kota Palembang. Jurnal.Radenfatah.Ac.Id, $14(1), \quad 107-123$. http://jurnal.radenfatah.ac.id/index.php/annisa/article/view/5085

Mahastanti, L. A. (2011). Faktor-Faktor Yang Dipertimbangkan Investor Dalam Melakukan Investasi. Jurnal Manajemen Teori dan Terapan| Journal of Theory and Applied Management, 4(3), 37-51. https://doi.org/10.20473/jmtt.v4i3.2424 
Vol. 6, No.01; 2022

ISSN: $2456-7760$

Manan, A. (2009). Aspek Hukum Dalam Penyelenggaraan Investasi di Pasar Modal Syariah Indonesia. Kencana.

Mudrajat Kuncoro. (2009). Metode Riset Untuk Bisnis \& Ekonomi Bagaimana Meneliti \& Menulis Tesis (Edisi 3). Penerbit Airlangga.

Nagy Robert A., O. R. W. (1994). Factors Influencing Individual Investor Behavior. Financial Analysts Journal, July-Aug, 63-68.

Ngkat, T. I., Di, I. I., \& Arat, J. A. W. A. B. (2015). ) Mery Citra Sondari. 595-606.

Noor, J. (2015). Metode Penelitian. Pranadamedia Group.

Nurul Huda, M. (2008). Investasi pada Pasar Modal Syariah (Cetakan Ke). Kencana Prenada Media Group.

Peristiwo, H. (2016). Analisis Minat Investor Di Kota Serang Terhadap Investasi Syariah Pada Pasar Modal Syariah. ISLAMICONOMIC: Jurnal Ekonomi Islam, 7(1), 37-52. https://doi.org/10.32678/ijei.v7i1.7

Robbins, S. P. . (2006). Prinsip-prinsip Perilaku Organisasi (Edisi Lima). Erlangga.

Septyanto, D. (2013). Faktor-Faktor Yang Mempengaruhi Investor Individu Dalam Pengambilan Keputusan Investasi Sekuritas Di Bursa Efek Indonesia (BEI Dihin. Jurnal Ekonomi, 4(2), 90-101.

Setiawati Devi. (2009). Perbedaan Komitmen Kerja Berdasarkan Orientasi Peran Gender. Depok: Universitas Gunadarma.

Siregar, S. (2014). Metode Penelitian Kuantitatif. Fajar Interpratama Mandiri.

Sjahrir. (1995). Tinjauan Pasar Modal. PT Gramedia Pustaka Utama.

Sugiyono. (2009)., Metode penelitian pendidikan. CV Alfabeta.

Sujarweni, V. W. (2015). Metodologi Penelitian Bisnis dan Ekonomi. Pustakabarupress.

Yusuf, M., Ichsan, R. N., \& Saparuddin. (2021). Determinasi Investasi dan Pasar Modal Syariah Terhadap Pertumbuhan Ekonomi di Indonesia. Jurnal Kajian dan Kebijakan Publik, 6(1), 397-401. 